\title{
A FENNTARTHATÓ FEJLŐDÉSI CÉLOK ÉS A GRI SZERINTI JELENTÉSTÉTEL KAPCSOLATÁNAK ELEMZÉSE
}

A nemzetközi közösség 2015-ben elfogadta a „Fenntartható Fejlődési Keretrendszer 2030 - Agenda 2030” című, a 2015 és 2030 közötti időszakra vonatkozó programot, mely 17 fenntartható fejlődési célt (Sustainable Development Goals, SDG) fogalmaz meg. A célok kidolgozásakor explicit igényként jelentkezett azok integrációja, ezáltal az egyes célok között számos átfedés fedezhető fel. Újdonságként jelenik meg, hogy az agenda a célok elérésére nemcsak az államokat, hanem valamennyi olyan szereplőt - így például a vállalatokat - cselekvésre hív fel, akinek/amelynek a tevékenysége társadalmi és gazdasági rendszerünk fenntarthatóságát jelentősen befolyásolja. A szerzők tanulmányukban a célok közötti átfedéseket a célokhoz kapcsolható GRI (Global Reporting Initiative) indikátorok alapján elemezték.

A kutatásban a fenntartható fejlődési célok közötti kapcsolatot klaszterelemzéssel vizsgálták. A kutatás eredményei alapján a GRI indikátorokkal indikált 17 célkitűzés közül 9 között rendkívül szoros kapcsolat áll fenn. Ennek oka elsősorban technikai, melyet a hozzárendelt (egyedi) GRI indikátorok száma okoz. Habár a többi célkitűzés esetén tárhatók fel kapcsolatok, hasonló erősségű mintázat nem fedezhető fel.

A fenntartható fejlődési célok kategorizálása alapján megállapítható, hogy a világ 250 nagyvállalata által priorizált és kevésbé priorizált célok felmerülési gyakorisága között a KPMG (2018) által bemutatottnál kisebb szóródás figyelhető meg. ${ }^{1}$

Kulcsszavak: fenntartható fejlődés, vállalati fenntarthatósági jelentéstétel, fenntartható fejlődési célok

A z ENSZ által 2012-ben megrendezett Rio+20 Fenntartható Fejlődési Konferencián döntés született a korábbi, 2000-ben elfogadott Millenniumi Fejlesztési Célok (Millennium Development Goals, MDG) nevü 15 éves program helyébe lépő, újabb 15 éves agenda összeállítására. A 2015-ben induló „Fenntartható Fejlődési Keretrendszer 2030 - Agenda 2030" című dokumentumot végül 193 ország írta alá, köztük például az USA, India, illetve Kína. Az agendához konkrét célkitűzések rendszerét dolgozták ki, melyet a fenntartható fejlődés céljainak (Sustainable Development Goals, a továbbiakban SDG) neveznek (ENSZ, 2015).

Az elfogadott 17 SDG egy olyan globális keretrendszert alkot, amely egyaránt lefedi a fenntartható fejlődés társadalmi, gazdasági és környezeti dimenzióját. A gyakorlatba való átültetés elősegítése érdekében a 17 célkitüzéshez 169 alcélt $^{1}$ (target), valamint 230 indikátort dolgoztak ki.

Az új keretrendszer két jelentős újdonságot hozott. Az egyik, hogy a millenniumi fejlődési célokkal szemben nemcsak a fejlődő, hanem a fejlett országok számára is feladatokat fogalmaz meg. A másik, hogy az agenda a célkitüzések elérését nemcsak az államok növekvő szerepvállalásától várja, hanem azt valamennyi releváns szereplö, így például az üzleti vállalkozások, illetve a civil szervezetek együttműködésével kívánja elérni.

A nagyvállalatok esetében egyre inkább teret nyer a fenntarthatóság üzleti gyakorlatba való átültetése: a
KPMG (2015) felmérése alapján a 250 legnagyobb vállalat (G250) 92 százaléka tesz közzé vállalati fenntarthatósági jelentést, de a jelentéstétel a többi gazdasági szereplő számára is egyre inkább elvárásnak tekinthető. A jelentéstételi gyakorlatok végrehajtása során kialakított folyamatok megfelelö alapot jelenthetnek ahhoz, hogy a cégek vállalásokat tegyenek és jelentsenek a globális célokhoz való szervezeti hozzájárulásukról.

A tanulmányban a vállalatok fenntartható fejlődési célok közötti kapcsolatait a leginkább elterjedt nem-pénzügyi jelentéstételi rendszer, a GRI (Global Reporting Initiative) kapcsolódó indikátorain keresztül vizsgáljuk.

A tanulmány a következőképp épül fel: elsőként a vállalati felelősségvállalással, a fenntartható fejlődési célokkal kapcsolatos irodalmat tekintjük át, majd az alkalmazott módszertant és az eredményeket mutatjuk be. Összefoglalásként megfogalmazzuk a következtetéseinket, illetve a kutatás korlátozásait, továbbá bemutatjuk a további kutatási irányokat.

\section{Elméleti keretek}

\section{A fenntartható fejlödés céljai}

A 2015-ben elfogadott „Fenntartható Fejlődési Keretrendszer 2030 - Agenda 2030" (továbbiakban: Agenda 2030) a 2015 és 2030 közötti időszakra vonatkozóan 17 fenntartható fejlődési célt (Sustainable Development Goals, SDG) fogalmaz meg. A célkitüzések operaciona-

\footnotetext{
${ }^{1}$ A tanulmány az MTA-BGE Makrogazdasági fenntarthatósági kutatócsoport, mint munkahely keretében, az MTA Támogatott Kutatócsoportok Irodájának támogatásával készült.
} 
lizálását 169, határidőt is megfogalmazó alcél (target), valamint 230 indikátor támogatja. A 17 SDG a következő: (1) szegénység felszámolása, (2) az éhezés megszüntetése, (3) egészség és jóllét, (4) minőségi oktatás, (5) nemek közötti egyenlöség, (6) tiszta víz és alapvető köztisztaság, (7) megfizethető és tiszta energia, (8) tisztességes munka és gazdasági növekedés, (9) ipar, innováció és infrastruktúra, (10) egyenlőtlenségek csökkentése, (11) fenntartható városok és közösségek, (12) felelős fogyasztás és termelés, (13) fellépés az éghajlatváltozás ellen, (14) óceánok és tengerek védelme, (15) szárazföldi ökoszisztémák védelme, (16) béke, igazság és erös intézmények, (17) partnerség a célok eléréséért (SDG Iránytü, 2015).

Az SDG-k kidolgozása során a célok közötti integráció explicit igényként jelentkezett. Az integráció következtében a célkitűzések és az alcélok közötti kapcsolat n:n típusú, azaz egy alcél több célkitüzéshez is kapcsolódhat. Az egyes célkitűzések közötti kapcsolat a célkitüzéseket egy gráf csúcsainak, az egy vagy több célkitűzéshez is kapcsolódó alcélokat pedig a gráf éleiként ábrázolva vizsgálható. A gráf elemzése alapján kitünik, hogy a célok közötti integráció foka jelentős szóródást mutat: míg a leginkább integráltnak tekinthető célkitüzések (felelős fogyasztás és termelés (SDG 12), illetve egyenlőtlenségek csökkentése (SDG 10) alcéljaik alapján rendre 14, illetve 12 másik célkitüzéssel állnak kapcsolatban, addig a megfizethető és tiszta energia (SDG 7) és az ipar, innováció és infrastruktúra (SDG 9) csak 3-3-mal, az óceánok és tengerek védelme (SDG 14) csak kettővel. Az elemzés alapján valamenynyi célkitűzés esetén elkülöníthetők az elsődleges (core), valamint a más célkitüzésnél is megjelenő kiterjesztett (extended) alcélok (Le Blanc, 2015)².

Az International Council for Science (ICSU) és az International Social Science Council (ISSC) a különböző célok közötti kapcsolatokat szakértők kis csoportjának megkérdezésével elemezte, mely alapján Le Blanc (2015) eredményeinél sủrübb kapcsolati háló rajzolódik ki (ICSU \& ISSC, 2015).

Muff és szerzőtársai (2017) rámutatnak arra, hogy a fejlett országok már 2015-ben, az Agenda 2030 indulásakor teljesítették a célkitüzések 70 százalékát, de egyes esetekben többet is, ami azt sugallja, hogy a célok teljesítéséért elsősorban a fejlödő világban szükséges tevékenykedni. Azonban fontos kiemelni, hogy mindez annak (is) az eredménye, hogy a társadalmi, illetve környezetvédelmi szempontból kifogásolható tevékenységeket részben vagy egészben a fejlődő világba szervezték ki (Xiao et al., 2017).

Az egyes országok, illetve térségek fenntartható fejlödéssel kapcsolatos eredményei és kihívásai eltérnek, így a javasolható beavatkozások köre is szükségszerűen eltérō. A leghatékonyabb beavatkozás(ok) meghatározását segítheti a Muff és szerzőtársai (2017) által összeállított Gap Frame. Az eszköz alapján megállapítható, hogy míg az OECD-országok esetében a klímaváltozás jelenti messze a legnagyobb kihívást, melyet a tengeri ökoszisztéma védelme, valamint a nemek közötti egyenlőség követ, addig például a fejlődő országokban a társadalmi integrációban, valamint a béke és az együttmüködés megteremtésében vannak a legnagyobb hiányosságok. A hulladékgazdálkodás azonban mindkét országcsoportban komoly problémát jelent.

Ezek az eredmények részben konzisztensek a KPMG (2018) által feltárt vállalati prioritásokkal, ahol a legnagyobb hangsúlyt szintén a klímaváltozás elleni küzdelem kapta, de a cégek fele hangsúlyozta a nemek közötti egyenlőség fontosságát is. Inkonzisztenciát okoz azonban, hogy a vállalatok az óceánok élővilágát tekintik a legkevésbé fontosnak, továbbá a hulladékgazdálkodás önállóan nem szerepel az SDG-k között. Ez utóbbi kétféleképp értelmezhető: (1) a hulladékgazdálkodást a környezeti SDGk közé sorolták be, ezért vállalati szempontból kevésbé hangsúlyos, (2) a hulladékkezelés nem független a fenntartható termeléstől, valamint fogyasztástól (SDG 12), ami a vállalatok számára a negyedik legfontosabb SDG.

A fenntartható fejlődés, a bolygó kapacitásainak eltartóképességét kutatva Kerekes és szerzőtársai (2018) két meghatározó müvet emelnek ki: az első a Római Klub 1972-es jelentése, a Növekedés határai, melyben a kutatók a nulla növekedés koncepciót támogatták.

A fenntarthatóságról szóló közgondolkodást hasonló mértékben változtatta meg Rockström és szerzőtársai (2009) a bolygó korlátai (planetary boundaries) modellje. A modell a Föld teherbíró képességét, vagyis az ökoszisztéma-szolgáltatásokat kilenc területen határozza meg: (1) a klímaváltozás, (2) az óceánok savasodása, (3) az ózonréteg elvékonyodása, (4) a nitrogén- és foszforciklus, (5) a vízhasználat, (6) a földhasználat változása, (7) a biológiai sokszínüség csökkenése, (8) a légköri aeroszol terhelése, (9) a kémiai szennyezés. A kilenc területből a kutatók akkor hetet tudtak számszerúsíteni. A koncepció lényege, hogy amennyiben az egyes szolgáltatásokból az éves felhasználás legfeljebb az éves termeléssel egyezik meg, akkor az emberiség fenntartható módon gazdálkodik, ellenkező esetben azonban a bolygó tartalékait éli fel.

A modellt Johan Rockström munkacsoportja több ponton is fejlesztette (Steffen et al., 2015):

(1) a szerzők az ökoszisztéma-szolgáltatások hierarchizálását javasolják, ennek keretében a magszolgáltatások közé az éghajlatváltozás, valamint a bioszféra integritása tartozik,

(2) pontosították az ökoszisztéma-szolgáltatások definícióit $^{3}$,

(3) a modell, amennyiben az releváns és számítható, differenciáltan kezeli a területi eltéréseket,

(4) az újabb modellszámítások alapján az ökológiai szolgáltatások éves termelését aktualizálták,

(5) a bioszféra integritása és a biokémiai áramlások esetén a Szerzők kétszintű megközelítést javasolnak, melynek keretében a szolgáltatásokat több, egymással összefüggő részszolgáltatásra bontják.

A modell szerint jelenleg a legsúlyosabb ökológiai probléma a biodiverzitás csökkenése, a fajok kipusztítása, míg a leginkább „népszerü” klímaváltozás csak a harmadik a sorban. Fontos azonban kiemelni, hogy a szolgáltatások között számos összefüggés is megfigyelhető, példá- 
ul a biodiverzitás csökkenéséhez jelentősen hozzájárul a földhasználat növekedése, amit egyaránt okozhat a mezögazdasági termelés, a bányászat vagy az építőipar (Bartus, 2017).

A koncepció alapjait nem, de részleteit számos kritika illette. A legfőbb kérdés a figyelembe veendő szolgáltatások számát illeti, ami szükségszerüen kihat a következtetésekre is. A TEEB (2010) tipológiájában az ökológiai szolgáltatások négy kategóriába sorolhatók: (1) ellátó szolgáltatások (provisioning services), (2) szabályozó szolgáltatások (regulating services), (3) fenntartó szolgáltatások (supporting services), (4) valamint kulturális szolgáltatások (cultural services). Raworth (2017) az ökológiai szolgáltatások körét szintén társadalmi és gazdasági szolgáltatásokkal egészítette ki, azonban azok egyszerű számszerüsítésén túllépve meghatározott egy olyan zöld (biztonsági) sávot, melyen belüli érték esetén az adott szolgáltatás használata fenntarthatónak tekinthetö. A modell alapján a társadalom és a politika szerepe kettős: úgy kell segítenie a társadalmi és/vagy gazdasági hiányosságok csökkentését, hogy közben meg kell akadályozni az ökológiai szolgáltatások túlzott igénybevételét.

Wood és szerzőtársai (2018) az SDG célokhoz tartozó alcélok és a TEEB (2010) által alkalmazott ökológiai szolgáltatások kapcsolatát szakértői kérdőívezés alkalmazásával vizsgálta. A kutatásban mind az SDG-k, mind az ökológiai szolgáltatások terén a környezettel kapcsolatos aspektusokat elemezték. Ezáltal az SDG-k közül közvetlen környezeti kapcsolattal nem rendelkezőket, valamint a közpolitikákkal kapcsolatosakat hagyták el, míg az ökoszisztéma-szolgáltatások közül elsősorban a kulturális szolgáltatások kerültek $\mathrm{ki}^{4}$ (ld. 1. táblázat). A szerzők eredményei alapján a vizsgált 12 SDG-ből csupán 5 köthető erősen az ökoszisztéma-szolgáltatásokhoz.

Az SDG koncepció alapja, hogy ,a prosperáló társadalmak elöfeltétele a stabil Föld rendszer (Earth system) fenntartása" (Steffen et al., 2015). Ennek a célnak a megvalósítása (optimális keretek között) csak globális koordinációval és összefogással valósulhat meg - melynek megfelelő eszköze lehet az SDG-k keretrendszere. Fontos hangsúlyozni, hogy nincs minden országra, illetve régióra alkalmazható megoldás - a különböző ökológiai szolgáltatásokat vizsgáló megközelítések ezt a helyspecifikus beavatkozásokkal segíthetik elö.

\section{A vállalatok szerepe a fenntartható fejlődési célok megvalósításában}

A globalizáció korában a transznacionális vállalatok (transnational companies, TNC) és a multinacionális vállalatok (multinational companies, MNC) nem ritkán az államok GDP-jéhez mérhető forgalmat bonyolítanak le, és ezzel párhuzamosan nemcsak a müködési területükhöz tartozó államok társadalmára gyakorolnak jelentős hatást, hanem a bolygó ökoszisztémájának egészére is. E vállalatokkal szemben megfogalmazott egyik leggyakoribb kritika, hogy müködésük túlnyúlik az egyes nemzetállamok szabályozási és szankcionálási keretein (Géring, 2014).

A megváltozott környezetben ,,a korábbi megosztás az állam és a gazdaság, a politikai/társadalmi és a gazdasági felelősség között már nem müködik, ezért a vállalatokat

1. táblázat Az ökoszisztéma-szolgáltatások és a fenntartható fejlődési célok (SDG) közötti kapcsolatok (Wood et al., (2018) alapján, saját szerkesztés)

\begin{tabular}{|c|c|c|c|}
\hline kategória & alkategória & indikátor kódja & indikátor neve \\
\hline \multirow[t]{2}{*}{ Gazdaság } & $\begin{array}{l}\text { Gazdasági } \\
\text { teljesítmény }\end{array}$ & G4-EC3 & Meghatározott juttatási és nyugdíjazáshoz kötődő tervvel kapcsolatos kötelezettségek \\
\hline & & G4-EC4 & Államtól kapott pénzügyi támogatás \\
\hline \multirow[t]{2}{*}{ Környezet } & $\begin{array}{l}\text { Beszállítók } \\
\text { környezetvédelmi } \\
\text { értékelése }\end{array}$ & G4-EN32 & Környezetvédelmi szempontból értékelt új beszállítók \\
\hline & & G4-EN33 & Negatív környezeti hatás a beszállítói láncban és a megtett intézkedések \\
\hline \multirow[t]{11}{*}{ Társadalom } & Beruházás & G4-HR1 & $\begin{array}{l}\text { Jelentős beruházások megállapodásai és szerződései, amelyek tartalmazzák az emberi } \\
\text { jogokra vonatkozó klauzulákat, és amelyek emberi jogok szempontjából megvizsgáltak }\end{array}$ \\
\hline & & G4-HR2 & Munkatársak képzése az emberi jogi politikákról és a folyamatokról \\
\hline & Értékelés & G4-HR9 & Emberi jogok szempontjából vizsgált müködési területek \\
\hline & $\begin{array}{l}\text { Emberi jogok } \\
\text { értékelése }\end{array}$ & G4-HR10 & Emberi jogi szempontból értékelt új beszállítók \\
\hline & & G4-HR11 & Negatív emberi jogi hatás a beszállítói láncban és a megtett intézkedések \\
\hline & Helyi közösségek & G4-SO1 & Helyi közösségek bevonása a müködésbe, hatásvizsgálatok és fejlesztési programok \\
\hline & $\begin{array}{l}\text { Szállítók társa- } \\
\text { dalmi szempontú } \\
\text { értékelése }\end{array}$ & G4-SO9 & Társadalmi követelmények szempontjából vizsgált új beszállítók \\
\hline & & G4-SO10 & Negatív társadalmi hatás a beszállítói láncban és a megtett intézkedések \\
\hline & $\begin{array}{l}\text { Ügyfelek egészsége } \\
\text { és biztonsága }\end{array}$ & G4-PR1 & $\begin{array}{l}\text { A termék- és szolgáltatáskategóriák egészségre és biztonságra gyakorolt hatásainak } \\
\text { értékelése }\end{array}$ \\
\hline & $\begin{array}{l}\text { Termékek és } \\
\text { szolgáltatások } \\
\text { címkézése }\end{array}$ & G4-PR5 & Ügyfélelégedettségi mérés eredménye \\
\hline & $\begin{array}{l}\text { Marketing- } \\
\text { kommunikáció }\end{array}$ & G4-PR6 & Tiltott vagy kifogásolt termékek értékesítése \\
\hline
\end{tabular}


már nem depolitizált, hanem politizált szereplőkként kell felfogni" (Géring, 2014, p. 56.). Ez azt jelenti, hogy a nagyvállalatoknak a korábbi passzív társadalmi (és környezeti) szerepvállalásuk helyett aktív szereplőként kell viselkedniük. Fontos kiemelni, hogy a szerepvállalás növekedése a legnagyobb jóindulat feltételezése mellett is elsősorban a vállalat tevékenységeire, annak szükebb környezetére korlátozódhat, ugyanis a tevékenységek tágabb környezetre vonatkozó, illetve globális hatásainak felmérése rendszerszintü megközelítést igényel (Harangozó és szerzőtársai, 2016).

A vállalati teljesítményt Harangozó (2008) szerint a hatékonyság, hosszú távú eredményesség, valamint az alkalmazkodóképesség határozza meg. Az eredményesség a megfelelő célok kitűzését és azok elérését, míg a hatékonyság a célok elérését az erőforrások optimális felhasználásával éri el (Carnall, 2003, p. 61.; Wimmer, 2007, p. 1. idézi Harangozó, 2008). Tekintettel arra, hogy a fenntartható fejlődési célok rendszerszintü megközelítést tükröznek, továbbá a célmeghatározás által az eredményességhez is hozzájárulnak, alkalmasak lehetnek mind a vállalati szint és globális szint közötti szakadék áthidalására, mind a vállalati erőforrások hatékony felhasználásának támogatására.

Az Agenda 2030 millenniumi fejlesztési célokhoz mért egyik újdonsága, hogy a globális célok elérésében a szereplők szélesebb körét nevezi meg, így felhívja az üzleti szféra szereplöit is, hogy „kreativitásukkal és innovációikkal járuljanak hozzá a fenntartható fejlődés által támasztott kihívások megoldásához" (ENSZ, 2015, p. 29.). Habár a dokumentum hangsúlyozza a vállalati szféra méret szerinti heterogenitását, a felelősségvállalással kapcsolatos intézkedések, a kommunikáció, valamint a müködés legitimációjáért való tevékenységek elsősorban a nagyvállalati szereplőket érintik.

A PwC (2015) felmérése alapján ugyan a vállalatok 71 százaléka tervezi, hogy valamilyen módon választ ad az SDG-k által jelentett kihívásokra, melyböl csupán 44 százalék tervezi a tevékenységük hatásának értékelését a cég szempontjából releváns célkitűzésekre. A vállalatok számára a legfőbb nehézséget az SDG-k száma, valamint az egymással való kapcsolataiknak komplexitása jelenti. Például egy agrárvállalkozásnak a (túlzott) mütrágya alkalmazásának a tengeri élővilágra gyakorolt hatása nem feltétlenül tekinthető magától értetődőnek.

A KPMG (2018) a 250 legnagyobb vállalat (G250) fenntarthatóság jelentésének részletes, tartalomra is kitérô áttekintése alapján megállapította, hogy a cégek csupán 40 százaléka foglalkozik SDG-vel a jelentésében. A leginkább priorizált SDG-k a fellépés a klímaváltozás ellen (SDG 13), a tisztességes munka és gazdasági növekedés (SDG 8), valamint az egészség és jóllét (SDG 3), melyeket a cégek több, mint fele említ. Érdekes módon az ökoszisztémával kapcsolatos célok (óceánok és tengerek védelme (SDG 14), szárazföldi ökoszisztémák védelme (SDG 15), valamint az éhezés megszüntetése (SDG 2) a jelentések negyedében sem jelenik meg. A PwC (2015) felmérése iparáganként is vizsgálta, hogy a cégek szerint tevékenységük mely célkitűzésekre gyakorolja a legnagyobb ha- tást. Az eredmény konzisztensnek tekinthető a KPMG (2018) által feltártakkal, mindazonáltal a vegyi és a kiskereskedelmi cégek értékelése alapján tevékenységük által öt legnagyobb hatással érintett célkitűzés közé sorolták az éhezés megszüntetését (SDG 2).

Zsóka és Vajkai (2018) 37 vállalati nem-pénzügyi jelentés elemzése alapján további problémaként emeli ki, hogy habár a vállalatok egyes tevékenységei a fenntartható fejlődésre pozitív és negatív irányba egyaránt hathatnak, a jelentésekben szinte kizárólag a pozitív aspektusok jelennek meg - azaz sérül a kiegyensúlyozottság elve. Hasonló következtetésre jutott a G250 vállalatot érintő kutatásában a KPMG (2018) az SDG-kre vonatkozóan.

Az újrapolitizált vállalat ellenpontját Géring (2014) szerint a Friedman (1970) által hangoztatott koncepció jelenti, mely szerint mivel a vállalat maga egy mesterséges (azaz jogi) személy, így a felelősségei is mesterségesek. Másképp fogalmazva a vállalatnak tulajdonított felelősségvállalás tulajdonképpen a menedzser felelősségvállalása. Friedman (1970) szerint mivel a menedzser a tulajdonos alkalmazottja, ezért neki a tulajdonos értékválasztását kell követnie, tehát a felelősségvállalása egyedül a részvényesek vagyonának maximalizálására terjedhet ki.

A részvényesi értékmaximalizálást és a felelősségvállalást Archie B. Carroll foglalta egy keretrendszerbe (például Carroll, 1991). Carroll úgy érvel, hogy a felelősségvállalás hozzájárulhat a profittermeléshez, azaz léteznek legalább zérus nettó jelenértékű felelősségvállalási projektek. Mivel ezekről a projektekről is a menedzserek döntenek, a vállalat magatartását végső soron jelentős mértékben befolyásolják a menedzserek személyiségei, értékei, attitüdjei (Benedek - Takácsné György, 2016). Ezek az értékek jelennek meg a vállalati jelentések elején szereplő vezetői üzenetben, melynek célja a főbb vezetői prioritások, célok, tapasztalatok érdekeltek felé történő megosztása. A KPMG (2018) kutatása alapján az SDG-ket a jelentésükben megemlítő vállalatok 39 százaléka esetében a vezérigazgató megemlítette az SDG-ket, vagyis a vizsgálatban szereplő 250 világcégnek csupán 16 százaléka rendelkezik e téren vezetői elkötelezettséggel.

\section{A GRI}

A vállalatok fenntarthatósági vállalásainak közzétételére számos eszköz áll rendelkezésre. Siew (2015) a vállalati fenntarthatóságról történő formális jelentéstétel három eszközét különíti el: (1) a nem-pénzügyi (vagy más néven fenntarthatósági) jelentések összeállítását standardizáló jelentéstételi rendszereket, (2) a különböző standardok szerinti tanúsítványokat, (3) valamint az értékelési (rating) rendszereket, indexeket. Harangozó és szerzőtársai (2016) negyedik eszközként említik a stratégiát, ide sorolva a WBCSD által kifejlesztett ökohatékonysági megközelítést, valamint a kiegyensúlyozott fenntarthatósági mutatószám-rendszereket (Sustainability Balanced Scorecard, $\mathrm{SBC}$ ). Jelen tanulmány a fenntarthatósági jelentéstételi rendszerekre fókuszál.

Habár a fenntarthatósági jelentéstétel célja elsősorban a vállalatok transzparenciájának növelése, valamint a közösségek bizalmának erősítése, a kritikusok szerint ez 
nem feltétlen valósul meg. A beszámolás legfőbb problémája az önkéntesség, ami lehetőséget biztosít a lényeges dolgok elkendőzésére, így a zöldre mosásra (greenwashing) (Hervieux et al., 2017). Laufer (2003) a Fortune 500 vállalatainak müködését vizsgálva állapította meg, hogy a vállalatok gyakran bocsátkoznak olyan stratégiákba és ellenstratégiákba, melyek alkalmasak arra, hogy az érdekeltek összezavarodjanak a cég céljait illetően, ezzel ásva alá a szavahihetőséget.

A G250-be tartozó vállalatok 92 százaléka tesz jelentést a fenntarthatósági teljesítményéről, mely beszámolók 74 százaléka pedig a Global Reporting Initiative (GRI) szerint készül. Habár némi a GRI-t alkalmazó vállalatok aránya 2013 óta némileg csökkent, továbbra is a legelterjedtebb keretrendszernek tekinthető (KPMG, 2015).

A GRI egy olyan keretrendszernek tekinthető, mely a világ bármely szervezete számára egyaránt alkalmazható, legyenek azok kicsik vagy nagyok. A GRI szerinti jelentéstétel alapelvei két csoportra, a jelentések tartalmára, illetve annak minőségére vonatkozó elvekre oszthatók (GRI, 2015). A keretrendszer módszertana folyamatosan fejlődik - habár számos vállalat a jelentését a korábbi módszertan szerint (pl. GRI G3 vagy G3.1) készíti, a GRI G4-et 2018 júliusában a GRI Standards váltotta fel (GRI, 2016b).

A szervezetek transzparenciája és elszámoltathatósága hozzájárulhat a fenntartható fejlődéshez, a fenntarthatósági jelentéstétel pedig ennek egy eszköze. A civil szervezettekkel közös projektek megvalósítása az elszámoltathatóság és a hitelesség elérésének egyik kézenfekvő módja lehet (Radácsi, 2016) - mindazonáltal minden ilyen együttmüködés teret enged a vállalati reputáció mosdatásának is (Laufer, 2003). A fenntarthatósági jelentés célja, hogy a szervezetek feltárják tevékenységük lényeges társadalmi, környezeti, vállalatirányítási és gazdasági aspektusait, ez pedig lehetővé teszi, hogy a müködés során a szervezet tudatosan törekedhessen a fenntartható fejlődés felé (GRI, 2016a). Ez a tevékenység nem feltételezi a szervezetről, hogy az altruista módon jár el - a fenntartható fejlődésre való törekvés ,a versenyképesség támogatásával csökkenti a vállalat kockázatát és kedvező irányba pozicionálja a globális piacon" (GRI, 2016a, p 5.).

A GRI az indikátorokat a fenntarthatóság hármas célrendszerének (Triple Bottom Line, TBL) megfelelően, társadalmi, gazdasági és környezeti dimenziókba osztja. A vállalat egészére vonatkozó, általános indikátorok negyedik dimenzióként foghatók fel.

Habár a GRI tekinthető ma a nem-pénzügyi jelentéstétel „globális szabványának” mind a GRI, mind az alapjául szolgáló TBL-koncepció kritika tárgyát képezi. Shridhar és Jones (2013) szerint a TBL három fő hiányossága a következö:

(1) a különböző dimenziók teljesítménye csak kompromisszumok mentén adható össze, ugyanis míg a gazdasági teljesítmény pénzben kifejezhető, addig a környezeti legfeljebb természetes mértékegységben mért naturáliákkal fejezhető ki (például $\mathrm{CO} 2$ ekvivalens kibocsátás), a társadalmi dimenzióra pe- dig csak különféle mutatók (például nemek aránya, képzési ráfordítás) állnak rendelkezésre. Ezt a tényt súlyosbítja, hogy a GRI indikátoraiban a társadalmi aspektusok felülreprezentáltak (Moneva et al., 2006), ami a GRI G4 esetén is fennáll. A szervezeti szintü teljesítmény megállapítása a különböző mértékegységek következtében vagy indexszámítással, vagy a különböző indikátorok pénzben való kifejezése által történhet (Slaper - Hall, 2011), melyek mindegyike jelentős torzításokat okoz.

(2) a TBL koncepció az általa érintett három dimenziót elkülönülten kezeli, ami a szervezetet arra ösztönzi, hogy egyensúlyra törekedjen. Sridhar és Jones (2013) elismeri, hogy egyes beavatkozások ellentétesen hathatnak a különböző dimenziókban elért teljesítményre, azonban mivel a fenntarthatóság fókuszpontjában épp a különböző hatások közötti integráció áll, így a szerzők a koncepció átdolgozását, az IBL (integrated bottom-line) alkalmazását sürgetik. E problémát hidalhatja át a Raworth (2017) által alkalmazott koncepció, mely a teljesítményt az indikátorok célértékeihez, vagy azok egy előre meghatározott intervallumához viszonyítja, ezáltal a különböző dimenziókban mért teljesítmények közötti átváltások (trade-off) explicit módon is megjeleníthetök.

(3) azáltal, hogy mind a kormányok és a nemzetközi szervezetek, mind a fenntarthatósági beszámolás szabványait kidolgozó szervezetek a TBL-t alkalmazzák, erös ösztönzés jelenik meg arra, hogy a valós elkötelezettség helyett a szervezetek csak az elöírásoknak való szimpla megfelelésre (compliance) törekedjenek.

További kritika, hogy a GRI a környezeti és társadalmi teljesítményindikátorok egy étlapját kínálja, melyből a választás a vállalatok számára a la carte történik - vagyis a kiválasztott indikátorok nem feltétlen tükrözik a fenntartható fejlődés holisztikus megközelítését (Parris - Kates, 2003 idézi Pintér et al., 2012, p. 22.). A kimazsolázott indikátorok szerinti jelentéstétel valóságtartalmát pedig független külső szereplők jellemzően nem ellenőrzik (Laufer, 2013). Mindezen problémák kapcsán fontos hangsúlyozni, hogy az önkéntes jelentéstétel, valamint a jelentések öszszeállításának szabadsága hozzájárulhat ahhoz is, hogy a vállalatok tevékenységükről egyre szívesebben és egyre több adatot osztanak meg (Pintér et al., 2012).

\section{A GRI és a fenntarthatósági fejlődési célok (SDG-k)}

\section{Módszertan}

A vállalatok fenntartható fejlődési célokkal kapcsolatos tevékenységeinek mérésére kézenfekvő megoldás lehet a már meglévő indikátorrendszerekkel való szinkronizálás. A megoldás azonban két problémát is felvet: (1) a különböző mérési keretrendszerek a jelenségek különböző aspektusaira vonatkoznak (Mancini et al., 2018), (2) a már meglévő (ready-to-use) indikátorrendszerek alkalmazá- 
sakor felmerül a kockázat, hogy a terminológia vagy a tartalom nem felel meg az indikátor-indikálandó jelenség (indicator-indicated fact) relációnak (Hák et al., 2016). Mindazonáltal fontos kiemelni, hogy az indikátorok által szolgáltatott adatok relevanciáját fokozhatja, hogy azokat nem globálisan, hanem vállalati léptékben határozzák meg (Pintér et al., 2012).

Tanulmányunkban a különböző SDG-k közötti kapcsolatokat az SDG Iránytű által javasolt GRI G4 indikátorok alapján végezzük $\mathrm{el}^{5}$. Az SDG Iránytű a GRI, az ENSZ Global Compact (UNGC) és a World Business Council of Sustainable Development (WBCSD) által fejlesztett módszertan, mely a segít feltárni az SDG-k és az üzleti folyamatok közötti kapcsolatokat, valamint eszközöket és útmutatást kínál arra, hogy hogyan lehet a fenntarthatóságot beépíteni az üzleti stratégiába. Az integrációs folyamat - mely nem tér el különösképpen más menedzsmentmegközelítések üzleti folyamatokba történő implementálásától - az alábbi öt lépcsőből áll (SDG Iránytü, é.n.): (1) a fenntartható fejlődési célok megértése, (2) prioritások meghatározása, (3) célok kitűzése, (4) integráció, (5) jelentéstétel és kommunikáció. Habár a folyamat önmagában is alkalmazható, további eszközök alkalmazásával bővíthető - Muff és szerzőtársai (2017) az első három lépés végrehajtását három további eszköz, a Gap Frame, a Business Sustainability 3.0 (BST 3.0) és a stakeholderekkel való közös gondolkodás (collaboratory) alkalmazásával javasolja.

A GRI indikátorokat az SDG alcélok szintjén határozták meg, elemzésünkben azokat közvetlenül a célokhoz rendeltük. Annak ellenére, hogy a célokhoz tartozó alcélok következtében egy GRI indikátor többször is szerepelhet egy SDG-nél, azt minden esetben egy indikátornak tekintettük.
A fenntartható fejlődési célok kidolgozása során explicit célként jelent meg, hogy azok integráltak legyenek, ezáltal elemezhetők az SDG-k közötti összefüggések, valamint az átfedések. Ezt Le Blanc (2015) az alcélok azonossága alapján hajtotta végre, míg jelen tanulmányban a célok közötti összefüggéseket a célokhoz kapcsolódó GRI indikátorok alapján vizsgáljuk.

A GRI-k homogén csoportokba sorolása a súlyozott szomszédsági mátrix alapján történhet, melyben a mátrix cellaértékei azt mutatják meg, hogy egy GRI melyik másikkal hány alkalommal ,találkozik”. Ez alapján jól látszanak az úgy nevezett GRI vektorok, melyek elhelyezik az GRI-ket egy n-dimenziós eukleidészi térben, így egyesek közel, mások távol kerülnek egymástól. Négyzetes eukleidészi távolságuk mértéke alapján pedig vélhetően besorolhatók, azaz összevonhatók homogén csoportokba. Az összevonásra a klaszteranalízis módszertana kínál lehetőséget. A klaszteranalízis egy úgynevezett dimenziócsökkentő eljárás, segítségével adattömböket tudunk klasszifikálni. Két fö irányban lehet mozogni, az egyik az úgynevezett hierarchikus klaszterezés, ami lehet öszszevonó, vagy felosztó. A másik a nem hierarchikus, vagy másképpen K-középpontú klaszterezés.

Az algoritmus lépései MacQueen 1967-ben megjelent írása (MacQueen, 1967) alapján:

- a klaszterek számának (k) kiválasztása,

- véletlenszerüen létrehoz k számú klasztert, meghatározza minden klaszter középpontját, vagy azonnal létrehoz $\mathrm{k}$ véletlenszerü klaszterközéppontot,

- minden egyes pontot a legközelebbi középponttal rendelkező klaszterbe sorol,

- az új klaszterközéppontok meghatározása,

\begin{tabular}{|c|c|c|c|}
\hline kategória & alkategória & indikátor kódja & indikátor neve \\
\hline \multirow[t]{2}{*}{ Gazdaság } & \multirow{2}{*}{ Gazdasági teljesítmény } & G4-EC3 & $\begin{array}{l}\text { Meghatározott juttatási és nyugdíjazáshoz kötődő tervvel kapcsolatos } \\
\text { kötelezettségek }\end{array}$ \\
\hline & & G4-EC4 & Államtól kapott pénzügyi támogatás \\
\hline \multirow[t]{2}{*}{ Környezet } & \multirow{2}{*}{$\begin{array}{l}\text { Beszállítók környezetvédelmi } \\
\text { értékelése }\end{array}$} & G4-EN32 & Környezetvédelmi szempontból értékelt új beszállítók \\
\hline & & G4-EN33 & Negatív környezeti hatás a beszállítói láncban és a megtett intézkedések \\
\hline \multirow{11}{*}{ Társadalom } & \multirow[t]{2}{*}{ Beruházás } & G4-HR1 & $\begin{array}{l}\text { Jelentős beruházások megállapodásai és szerződései, amelyek tartal- } \\
\text { mazzák az emberi jogokra vonatkozó klauzulákat, és amelyek emberi } \\
\text { jogok szempontjából megvizsgáltak }\end{array}$ \\
\hline & & G4-HR2 & Munkatársak képzése az emberi jogi politikákról és a folyamatokról \\
\hline & Értékelés & G4-HR9 & Emberi jogok szempontjából vizsgált müködési területek \\
\hline & \multirow{2}{*}{ Emberi jogok értékelése } & G4-HR10 & Emberi jogi szempontból értékelt új beszállítók \\
\hline & & G4-HR11 & Negatív emberi jogi hatás a beszállítói láncban és a megtett intézkedések \\
\hline & Helyi közösségek & G4-SO1 & $\begin{array}{l}\text { Helyi közösségek bevonása a müködésbe, hatásvizsgálatok és fejlesztési } \\
\text { programok }\end{array}$ \\
\hline & \multirow{2}{*}{$\begin{array}{l}\text { Szállítók társadalmi szempontú } \\
\text { értékelése }\end{array}$} & G4-SO9 & Társadalmi követelmények szempontjából vizsgált új beszállítók \\
\hline & & G4-SO10 & Negatív társadalmi hatás a beszállítói láncban és a megtett intézkedések \\
\hline & $\begin{array}{l}\text { Ügyfelek egészsége és bizton- } \\
\text { sága }\end{array}$ & G4-PR1 & $\begin{array}{l}\text { A termék- és szolgáltatáskategóriák egészségre és biztonságra gyakorolt } \\
\text { hatásainak értékelése }\end{array}$ \\
\hline & $\begin{array}{l}\text { Termékek és szolgáltatások } \\
\text { címkézése }\end{array}$ & G4-PR5 & Ügyfélelégedettségi mérés eredménye \\
\hline & Marketingkommunikáció & G4-PR6 & Tiltott vagy kifogásolt termékek értékesítése \\
\hline
\end{tabular}

2. táblázat Fenntartható fejlődési alcélhoz nem kapcsolódó gazdasági, környezeti, illetve társadalmi GRI G4 indikátorok (SDG Compass (é.n.) alapján, saját szerkesztés) 
- iteráció, amíg egy előre megadott konvergenciakritérium (például besorolás nem változik) nem teljesül.

Az algoritmus előnye az egyszerüség és a sebesség, hátránya, hogy eltérö eredményt adhat a futtatások során, mivel az eredményét befolyásolja a kezdeti random besorolás. A módszer minimalizálja a klasztereken belüli varianciát, de nem minimalizálja az összvarianciát. A kis adattábla ellenére az egyszerüség, gyorsaság, valamint az előre megadható számú középpont alapján ezt a módszert választottuk.

\section{Eredmények}

A GRI G4 környezeti, társadalmi, gazdasági, valamint a szervezet egészére vonatkozó, általános kategóriába sorolható 149 indikátora közül a 17 fenntartó fejlődési célhoz 90 került hozzárendelésre ${ }^{6}$, melyből összesen 244
indikátor-SDG kapcsolat áll elö. A GRI indikátorok közül 60-t nem rendeltek célhoz, ebből 2-2 a gazdasági, illetve környezeti, 11 pedig a társadalmi dimenzióhoz tartozik. A kimaradt, nem általános indikátorok az ellátási láncra, a helyi közösségre, a munkavállalói képzésre, valamint a vevői elégedettségre vonatkoznak, így ezek esetében nem feltétlen állapítható meg közvetlen kapcsolat a globális megközelítésű SDG-kkel (ld. 2. táblázat). A fennmaradó 45 a vállalat egészére vonatkozó, általános indikátor, melyek összerendelésből való elhagyása további magyarázatot nem igényel. ${ }^{7}$

Az egyes fenntartható fejlődési célokhoz tartozó indikátorok száma jelentősen eltér: míg a Fenntartható városok és közösségek (SDG 11) és a Partnerség a célok eléréséért (SDG 17) célokhoz 2-2, addig a Tisztességes munka és gazdasági növekedéshez (SDG 8) 39 egyedi indikátor tartozik. Elmondható, hogy 7 SDG-hez (41 százalék) tíznél kevesebb GRI indikátor tartozik, 6 célhoz 10 és 20 közötti
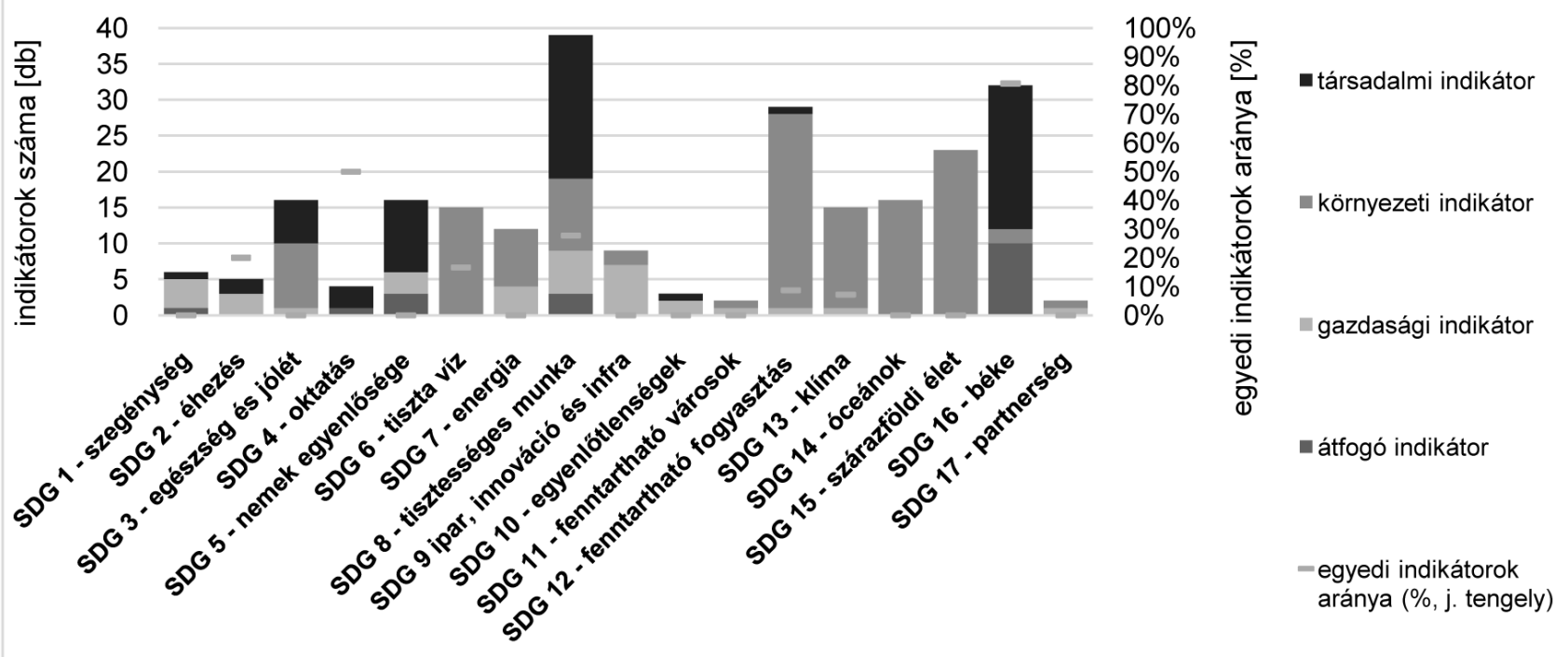

1. ábra A fenntartható fejlődési célokhoz (SDG) kapcsolódó GRI indikátorok típusa és száma (db), valamint az egyedi indikátorok aránya (\%) (saját szerkesztés)

\begin{tabular}{|c|c|c|c|}
\hline & környezet & társadalom & gazdaság \\
\hline tiszta dominancia & $\begin{array}{l}\text { tiszta víz és alapvetö köztisztaság } \\
\text { (SDG 6), }\end{array}$ & & \\
\hline \multicolumn{4}{|l|}{$\begin{array}{l}\text { felelős fogyasztás és termelés } \\
\text { (SDG 12), }\end{array}$} \\
\hline \multicolumn{4}{|l|}{$\begin{array}{l}\text { fellépés az éghajlatváltozás ellen } \\
\text { (SDG 13), }\end{array}$} \\
\hline \multicolumn{4}{|l|}{$\begin{array}{l}\text { óceánok és tengerek védelme } \\
\text { (SDG 14), }\end{array}$} \\
\hline $\begin{array}{l}\text { szárazföldi ökoszisztémák védelme } \\
\text { (SDG 15) }\end{array}$ & minőségi oktatás (SDG 4) & $\begin{array}{l}\text { ipar, innováció és infrastruktúra } \\
\text { (SDG 9) }\end{array}$ & \\
\hline erős dominancia & & szegénység felszámolása (SDG 1) & \\
\hline $\begin{array}{l}\text { csak specifikus indikátorokkal mérve } \\
\text { domináns }\end{array}$ & & $\begin{array}{l}\text { nemek közötti egyenlőség (SDG } \\
5),\end{array}$ & \\
\hline \multicolumn{4}{|l|}{$\begin{array}{l}\text { béke, igazság és erôs intézmények } \\
\text { (SDG 16) }\end{array}$} \\
\hline csak $2 / 3$ arányban domináns & $\begin{array}{l}\text { megfizethetö és tiszta energia } \\
\text { (SDG 7) }\end{array}$ & & $\begin{array}{l}\text { egyenlötlenségek csökkentése } \\
\text { (SDG 10) }\end{array}$ \\
\hline nincs domináns dimenzió & \multicolumn{3}{|c|}{$\begin{array}{l}\text { éhezés megszüntetése (SDG 2), egészség és jóllét (SDG 3), tisztességes munka és gazdasági növekedés } \\
\text { (SDG 8), fenntartható városok és közösségek (SDG 11), partnerség a célok eléréséért (SDG 17) }\end{array}$} \\
\hline
\end{tabular}

3. táblázat A GRI indikátorok dimenzióinak súlya az egyes fenntartható fejlődési célokon belül (saját szerkesztés) 
indikátort rendeltek, míg négy cél esetében 20-nál több indikátort állapítottak meg. Tíz SDG-hez nem tartozik olyan indikátor, mely más célnál ne fordulna elö, további két SDG esetén az egyedi indikátorok aránya nem éri el a 10 százalékot. A legtöbb egyedi indikátor a Béke, igazság és erös intézményekhez (SDG 16) tartozik, de arányuk a Minőségi oktatás (SDG 4) esetén is jelentős (ld. 1. ábra).

A TBL által meghatározott klasszifikáció alapján vizsgálható, hogy a célok döntően a TBL mely dimenziójához tartoznak. A vizsgálatot két változatban (az általános indikátorokkal együtt és azoktól tisztítottan), valamint két küszöbérték $(66,6$, illetve 75 százalék) mentén végeztük el. Döntő súlyúnak azt a dimenziót tekintettük, melynek indikátorai az összes indikátoron belül legalább a küszöbértéknek megfelelő arányt képviselnek.

Az elemzések alapján megállapítható, hogy (1) hét cél esetében tiszta dominancia állapítható meg, vagyis 75 százalékos küszöbérték mellett mind az általános indikátorokkal, mind azok nélkül van egy döntő dimenzió, (2) egy esetben erős dominancia van. Ebben az esetben az általános indikátorokkal együtt vizsgálva csak a 66,6 százalékos küszöbérték mellett volt döntő a dimenzió, (3) két esetben csak a specifikus indikátorokkal mérve volt megfigyelhető dominancia, akkor viszont a 75 százalékos küszöbérték mellett, (4) szintén két esetben csak 66,6 százalékos küszöbérték mellett találtunk domináns irányt, igaz, ezek esetében az általános indikátorok nem játszottak szerepet, (5) öt esetben nem állapítható meg domináns dimenzió. Az egyes SDG-k besorolását a 3. táblázat tartalmazza.

A GRI indikátorokkal indikált SDG-k klaszterelemzését három szcenárióban végeztük el: (1) az egyedi és a közös GRI indikátorok súlyozott szomszédsági mátrixán, (2) a célkitűzésekhez tartozó GRI indikátorok eltérő száma következtében az egyedi és a közös GRI indikátorok normalizált szomszédsági mátrixán, (3) a kapcsolat egyszerü tényét vizsgálva az egyedi és a közös GRI indikátorok súlyozatlan szomszédsági mátrixán.

A súlyozott mátrixon végzett mindkét elemzés alapján megállapítható, hogy a GRI indikátoraik alapján 9 célkitűzés (SDG 1-2, SDG 4, SDG 7, SDG 9-11; SDG 16-17) egészen a 7 klaszteres felosztásig azonos klaszterbe kerül besorolásra. A klaszterbe való bekerülést elsősorban nem a tartalmi megfontolások, hanem GRI indikátorokkal való összerendelés okozza. Ezt jól mutatja, hogy a 9 célkitüzés 75, ebből 27 egyedi GRI indikátorral leírható. Habár a nemek közötti egyenlőség (SDG 5) a nem normalizált mátrixon végzett elemzések során a 6 klaszteres felosztásig az előzőekkel azonos klaszterbe kerül besorolásra, a klaszterközépponttól valamennyi esetben a legtávolabbi elemnek tekinthető.

A tisztességes munka és gazdasági növekedés (SDG 8) a súlyozott mátrixokon végzett klaszterelemzések során rendre önálló klasztert alkotott - ez alól egyedüli kivétel a nem normalizált mátrixon a kétklaszteres felosztás, ahol a Felelős fogyasztás és termelés (SDG 12) került önálló klaszterbe. Az elkülönülés oka ebben az esetben is inkább technológiai, ugyanis a célkitűzéshez 36 (ebből 10 egyedi) GRI indikátort rendeltek hozzá, melyek szinte valamennyi egyéb célkitűzéshez kapcsolódást biztosítanak, így a többi klaszter középpontjától vett távolság minden esetben meglehetősen nagy.

Habár a környezettel kapcsolatos célkitüzések (SDG 13-15) közötti eukleidészi távolság viszonylag kicsi, a korábbiakban bemutatottakhoz hasonló erősségű mintázat nem rajzolódik ki. A hasonlóságot ennek ellenére jól mutatja, hogy normalizált mátrixon az ötklaszteres felosztásig rendre azonos klaszterbe kerülnek (4. táblázat).

\section{Következtetések}

A tanulmányban a „Fenntartható Fejlődési Keretrendszer 2030 - Agenda 2030-ban" megfogalmazott 17 fenntartható fejlödési cél (Sustainable Development Goals, SDG) szerepét vizsgáltuk a felelős vállalati jelentéstételben. A téma aktualitását az adja, hogy az Agenda 2030ban explicit megfogalmazzák a vállalati közremüködésre vonatkozó igényt a globális célkitüzések megvalósításában (ENSZ, 2015). A vállalati nem-pénzügyi jelentéstételben való megjelenést a célok GRI (Global Reporting Initiative) G4 indikátoraival való kapcsolata alapján vizsgáltuk. A célok és az indikátorok közötti összerendeléshez a GRI, az ENSZ Global Compact (UNGC) és a World Business Council of Sustainable Development (WBCSD) által fejlesztett SDG Iránytüt használtuk fel.

Eredményeink alapján megállapítható, hogy a 17 SDGből 7 SDG-hez (41 százalék) csak tíznél kevesebb indikátor tartozik, hathoz 10 és 20 közötti indikátort rendeltek, míg négy cél esetében 20-nál több indikátort állapítottak meg. A legtöbb, szám szerint tíz cél esetében nincs olyan indikátor, mely más célnál ne jelenne meg, de csak öt esetében haladja meg az egyedi indikátorok aránya a 10 százalékot.

A klaszterelemzés alapján megállapíthatjuk, hogy a GRI indikátorokkal indikált célkitüzések közül 9 (SDG 1-2, SDG 4, SDG 7, SDG 9-11; SDG 16-17) között rendkívül szoros kapcsolat fedezhetö, ugyanis azok a hétklaszteres felosztásig minden esetben azonos klaszterbe kerülnek. A Tisztességes munka és gazdasági növekedés (SDG 8) a súlyozott, de nem normalizált szomszédsági mátrixon végzett kétklaszteres felosztás kivételével valamennyi elemzésben önálló klasztert alkotott, azaz a többi SDGtől jelentős mértékben különbözik. Habár a környezettel kapcsolatos célkitűzések (SDG 13-15) közötti eukleidészi távolság viszonylag kicsi, az elözőekhez hasonló erősségü mintázat nem rajzolódik ki (5. táblázat).

Elemzéseink árnyalhatják a KPMG (2018) eredményeit, ugyanis (1) a 11 kevésbé vagy mérsékelten priorizált célkitüzés közül 8 (SDG 1-2; SDG 7, SDG 9-11, SDG 1617) a GRI indikátorait tekintve egy klaszterbe sorolható, (2) a második leginkább priorizált SDG 8 elkülönült csoportot alkot, (3) az ökoszisztémával kapcsolatos célkitüzések (SDG 14-15) egymás közötti, valamint a vállalatok által legmagasabbra priorizált célkitűzés (SDG 13) közötti eukleidészi távolsága kicsi, ezáltal azok alacsony priorizáltsága az indikátorok hasonlóságával magyarázható.

A KPMG (2018) eredményei alapján e célok a G250 vállalat nem-pénzügyi jelentéseinek homlokterében állnak. Lehatárolható ezen kívül három függetlennek nevezhető cél (minőségi oktatás (SDG 4), fenntartható városok és közösségek (SDG 11), béke, igazság és erős intézmények 
(SDG 16)), melyek ugyan szintén kapcsolatban állnak a többi céllal, de a kapcsolat erőssége egy másik cél esetében sem ér el kritikus szintet. A fennmaradó 11 cél között jelentős mértékü azonosságok figyelhetők meg, melynek szélsőséges példája a két, ökoszisztémával kapcsolatos cél (óceánok és tengerek védelme (SDG 14) és szárazföldi ökoszisztémák védelme (SDG 15)) indikátorainak szinte teljes egyezése.

A következtések legfőbb korlátját a célok és a GRI indikátorok összerendelése jelenti. Egyrészt az SDG-k és a GRI indikátorok scope-ja eltérő - míg előbbi globális célokat fogalmaz meg, addig utóbbi egy szervezet hatáskörébe tartozó hatásokat mér. Másrészt az SDG Iránytüben szereplö megfeleltetést szakértői vélemények alapján állították öszsze, melyben torzítások fordulhatnak elő. További problémát okozhat, hogy mivel az SDG-k meghatározása egy politikai folyamat volt, a hangsúlyokat befolyásolhatták az egyes tárgyaló felek alkupozíciói.

További kutatási irányként a szektorális GRI indikátorok és az SDG-k közötti kapcsolatok mélyebb elemzése, valamint Muff és szerzőtársai (2017) által javasolt gap frame, és/ vagy Raworth (2017) modelljének vállalatokra való adaptációja jelölhető ki.

\section{Felhasznált irodalom}

Bartus, G. (2017): Miért nem képesek a társadalmak megfékezni a természeti környezet pusztulását? Az érdemi és hatékony környezetpolitika körvonalai. In: Jakab A. - Urbán L. (szerk.): Hegymenet. Társadalmi és politikai kihívások Magyarországon. Budapest: Osiris

Benedek, A. - Takácsné György, K. (2016): A felelős vállalatirányítás személyi tényezői: A CSR-központ felelős vállalatvezetők attitűdjének vizsgálata a kis- és középvállalatok körében. Vezetéstudomány/Budapest Management Review, 47 (1), p. 58-67.

Carroll, A. B. (1991): The pyramid of corporate social responsibility: Toward the moral management of organizational stakeholders. Business Horizons, July-August, p. 39-48. https://doi.org/10.1016/0007-6813(91)90005-g

ENSZ (2015): Transforming our world: the 2030 Agenda for Sustainable Development. http://www.un.org/ga/search/ view doc.asp?symbol=A/RES/70/1\&Lang $=\mathrm{E}$ letöltve: 2018.04.12

Friedman, M. (1970): The social responsibility of business is to increase its profits. The New York Times Magazine, September 13. https://www.colorado.edu/studentgroups/ libertarians/issues/friedman-soc-resp-business.html letöltve: 2017.12 .20

Géring, Zs. (2014): Profit és/vagy közösségi szerepvállalás? Vállalati társadalmi felelősségvállalás vezetői szemmel. Vezetéstudomány/Budapest Management, 45 (12)., p. 53-66.

GRI (2015) Reporting principles and standard disclosures https://www.globalreporting.org/resourcelibrary/ GRIG4-Part1-Reporting-Principles-and-StandardDisclosures.pdf letöltve: 2018. 04. 16.

GRI (2016a): 2016-2020 GRI's Contribution to Sustainable Development https://www.globalreporting.org/resourcelibrary/ GRI $\% 27 \mathrm{~s} \% 20$ Contribution $\% 20$ to $\% 20$ Sustainable $\% 20 \mathrm{De}$ velopment \%202016-2020\%20(2).pdf letöltve: 2018.04.30.
GRI (2016b): First Global Sustainability Reporting Standards Set to Transform Business https://www.globalreporting.org/information/news-and-press-center/Pages/ First-Global-Sustainability-Reporting-Standards-Set-toTransform-Business.aspx letöltve: 2018. 10. 22.

Hák, T. - Janoušková, S. - Moldan, B. (2016): Sustainable Development Goals: A need for relevant indicators. Ecological Indicators, 60, p. 565-573. https://doi. org/10.1016/j.ecolind.2015.08.003.

Harangozó, G. (2008): Mitől zöld egy vállalat - avagy mit is jelent a jó környezeti teljesítmény? (What makes a company green - or what does good environmental performance mean?). Vezetéstudomány/Budapest Management Review, 39 (1)., p. 27-36.

Harangozó, G. - Széchy, A. - Zilahy, Gy. (2016): A fenntarthatósági lábnyom-megközelítések szerepe a vállalatok fenntarthatósági szempontú teljesítményértékelésében. Vezetéstudomány/Budapest Management Review, 47 (7), p. 2-13.

Hervieux, C. - McKee, M. - Driscoll, C. (2017): Room for improvement: Using GRI principles to explore potential for advancing PRME SIP reporting. The International Journal of Management Education, 15., p. 219-237. http:// dx.doi.org/10.1016/j.ijme.2017.03.011

ICSU, ISSC (2015): Review of the Sustainable Development Goals: The Science Perspective. Paris: International Council for Science (ICSU) https://www.icsu.org/ cms/2017/05/SDG-Report.pdf letöltve: 2018. 04. 27.

Kerekes, S. - Marjainé Szerényi, Zs. - Kocsis, T. (2018): Sustainability, environmental economics, welfare. Budapest: Corvinus University of Budapest

KPMG (2013): The KPMG Survey of Corporate Responsibility Reporting 2013. https://assets.kpmg.com/content/ $\mathrm{dam} / \mathrm{kpmg} / \mathrm{pdf} / 2015 / 08 / \mathrm{kpmg}$-survey-of-corporate-responsibility-reporting-2013.pdf letöltve: 2018.10 .12

KPMG (2015): Currents of Change. The KPMG Survey of Corporate Responsibility Reporting 2015. https://home. kpmg.com/content/dam/kpmg/pdf/2015/12/KPMG-survey-of-CR-reporting-2015.pdf letöltve: 2018.04.22

$K P M G$ (2018): How to report on the SDG-s. What good looks like and why it matters. https://assets.kpmg.com/ content/dam/kpmg/xx/pdf/2018/02/how-to-report-onsdgs.pdf letöltve: 2018. 03. 20.

Laufer, W. S. (2003): Social Accountability and Corporate Greenwashing. Journal of Business Ethics, 43., p. 253261. https://doi.org/10.1023/A:1022962719299

Le Blanc, D. (2015): Towards integration at last? The sustainable development goals as a network of targets. UN Department of Economic and Social Affairs Working Paper No. 141 http://www.un.org/esa/desa/papers/2015/ wp141_2015.pdf letöltve: 2018.04.27

MacQueen, J. (1967): Some Methods for Classification and Analysis of Multivariate Observations. Proceedings of the 5th Berkeley Symposium on Mathematical Statistics and Probability, 1, p. 281-297.

Mancini, L. - Sala, S. (2018): Social impact assessment in the mining sector: Review and comparison of indicators frameworks. Resources Policy, 57., p. 98-111. https://doi. org/10.1016/j.resourpol.2018.02.002 
Moneva, J. M. - Archel, P. - Correa, C. (2006): GRI and the camouflaging of corporate unsustainability. Accounting Forum, 30, p. 121-137. http://dx.doi. org/10.1016/j.accfor.2006.02.001

Muff, K. - Kapalka, A. - Dyllick, T. (2017): The Gap Frame - Translating the SDGs into relevant national grand challenges for strategic business opportunities. The International Journal of Management Education, 15., p. 363-383 http://dx.doi.org/10.1016/j.ijme.2017.03.004

Pintér, L. - Hardi, P. - Martinuzzi, A. - Hall, J. (2012): Bellagio STAMP: Principles for sustainability assessment and measurement. Ecological Indicators, 17., p. 20-28 https://doi.org/10.1016/j.ecolind.2011.07.001

$P w C$ (2015): Make it your business: Engaging with the Sustainable Development Goals. https://www.pwc. com/gx/en/sustainability/SDG/SDG\%20Research_FINAL.pdf letöltve: 2018.11.30.

Radácsi, L. (2016): Üzleti és civil szervezetek együttmüködése Magyarországon. In: Radácsi, L. (szerk.): Üzleti és civil szervezetek együttmüködése Magyarországon. Budapest: Publio Kiadó Kft., p. 5-42.

Raworth, K. (2017): Doughnut Economics: Seven Ways to Think Like a 21st-Century Economist. London: Random House Business Books, Epub ISBN: 9781473517813

Rockström, J. - Steffen, W. - Noone, K. - Persson, A. - Chapin, F. S. - Lambin, E. - Lenton, T. M. - Scheffer, M. Folke, C. - Schellnhuber, H. - Nykvist, B. - De Wit, C. A. - Hughes, T. - van der Leeuw, S. - Rodhe, H. - Sörlin, S. - Snyder, P. K. - Costanza, R. - Svedin, U. ᄀ-Falkenmark, M. - Karlberg, L. - Corell, R. W. - Fabry, V. J. - Hansen, J. - Walker, B. - Liverman, D. - Richardson, K. - Crutzen, P. - Foley, J. (2009): Planetary boundaries: exploring the safe operating space for humanity. Ecology and Society 32., https://doi.org/10.5751/es-03180-140232

Scherer, A. G. - Rasche, A. - Palazzo, G. - Spicer, A. (2016): Managing for Political Corporate Social Responsibility: New Challenges and Directions for PCSR 2.0. Journal of Management Studies, 53, p. 273-298. https://doi.org/10.1111/joms.12203

SDG Iránytü (é.n.) https://sdgcompass.org/

Shridhar, K. - Jones, G. (2013): The three fundamental criticisms of the Triple Bottom Line approach: An empirical study to link sustainability reports in companies based in the Asia-Pacific region and TBL shortco- mings. Asian Journal of Business Ethics, 2., p. 91-111. https://doi.org/10.1007/s13520-012-0019-3

Siew, R. Y. J. (2015): A review of corporate sustainability reporting tools (SRTs). Journal of Environmental Management, 164., p. 180-195. https://doi.org/10.1016/j. jenvman.2015.09.010

Slaper, T. F. - Hall, T. J. (2011): The Triple Bottom Line: What Is It and How Does It Work? Indiana Business Review, Spring Volume 86, No. 1, http://www.ibrc.indiana. edu/ibr/2011/spring/article2.html letöltve: 2018. 04. 28.

Steffen, W. - Richardson, K. - Rockström, J. - Cornell, S. E. - Fetzer, I. - Bennett, E. M. - Biggs, R. - Carpenter, S. R. - de Vries, W. - de Wit, C. A. - Folke, C. - Gerten, D. Heinke, J.-Mace, G. M. - Persson, L. M. - Ramanathan, V. - Reyers, B. - Sörlin, S. (2015): Planetary boundaries: Guiding human development on a changing planet. Science, 347., https://doi.org/10.1126/science.1259855

TEEB (2010): The Economics of Ecosystems and Biodiversity Ecological and Economic Foundations. Edited by Pushpam Kumar. Earthscan, London and Washington http://www.teebweb.org/publication/the-economics-of-ecosystems-and-biodiversity-teeb-ecologicaland-economic-foundations/

(idézett cikk) Wimmer, Á. (2007) Harangozó Gábor: Mitől zöld egy vállalat - avagy mit is jelent a jó környezeti teljesítmény? c. kéziratának értékelése

Wood, S. L. R.-Jones, S. K. - Johnson, J. A. - Brauman, K. A. - Chaplin-Kramer, R. - Fremier, A. - Girvetz, E. - Gordon, L. J. - Kappel, C. V. -Mandle, L. - Mulligan, M. - O'Farrell, P. - Smith, W. K. - Willemen, L. -Zhang, W.-DeClerck F. A. (2018): Distilling the role of ecosystem services in the Sustainable Development Goals. Ecosystem Services, 29., p. 70-82. https://doi. org/10.1016/j.ecoser.2017.10.010

Xiao, Y. - Norris, C. B. - Lenzen, M. - Norris, M. G. Murray, J. (2017): How Social Footprints of Nations Can Assist in Achieving the Sustainable Development Goals. Ecological Economics, 135., p. 55-65. http:// dx.doi.org/10.1016/j.ecolecon.2016.12.003

Zsóka, Á. - Vajkai, É. (2018): Corporate sustainability reporting: Scrutinising the requirements of comparability, transparency and reflection of sustainability performance. Society and Economy, 40, 1., p. 19-44. https:// doi.org/10.1556/204.2018.40.1.3.

\footnotetext{
${ }^{1}$ A KSH nómenklatúrájában részcélként nevezik.

${ }^{2}$ Le Blanc (2015) az elemzésböl a célok és az alcélok közül kiszürte azokat, melyek nem konkrét célkitűzést fogalmaztak meg, hanem azok elérésének eszközeit (means of implementation) érintették. A szürést követően az elemzés 16 célt (a partnerség a célok eléréséért (SDG 17) kiszürésre került), valamint 107 alcélt tartalmazott.

${ }^{3}$ Steffen és szerzőtársai (2015) a nitrogén és foszfor ciklus helyett biokémiai áramlások, a biológiai sokszínűség csökkenése helyett pedig a bioszféra integritás megnevezést használják.

${ }^{4}$ Díszítő anyagok (ornamental resources), genetikai diverzitás fenntartása (maintenance of genetic diversity), esztétikai élmények (aesthetic information), müvészeti, kulturális és tervezési inspiráció (inspiration for art, culture, design), információ (information), szellemi gazdagodás (cognitive development).

${ }^{5}$ Az adatok letöltése 2018. március 25-én történt.

${ }^{6}$ A GRI-indikátorkészletből 89, továbbá egy, a beszerzésekre vonatkozó iránymutatásokból.

${ }^{7}$ A fenntartható fejlődési alcélhoz nem rendelt GRI-indikátorok teljes listája, valamint az alcélok és a GRI-indikátorok összerendelésének teljes listája helyhiány miatt az https://bit.ly/2Gsvuwm linken található.
} 


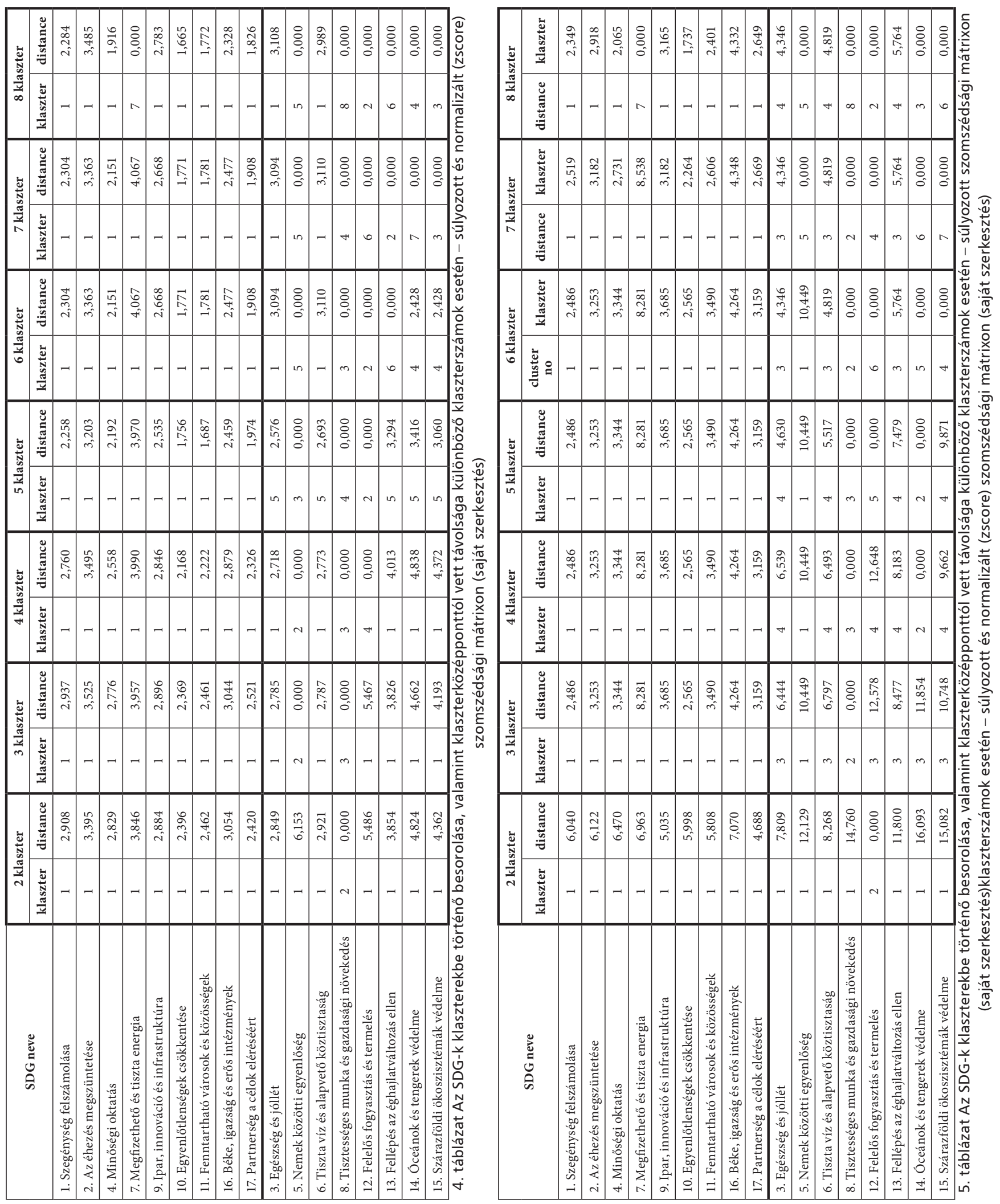

